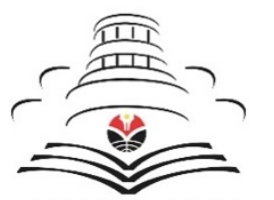

JURNAL UPI

\section{JAPANEDU:}

\section{Jurnal Pendidikan dan Pengajaran Bahasa Jepang}

http://ejournal.upi.edu/index.php/japanedu/index

\title{
War in Ippeisotsu's by Katai Tayama
}

\author{
Ahmad Fikri Ramadhani, Esther Risma Purba \\ Departement of Japanese Literature \\ Brawijaya University, Malang, Indonesia \\ fikri.rmdhni31@gmail.com estherpurba@ub.ac.id
}

\begin{abstract}
A B S T R A C T
The main objective of this research is to analyze the binary opposition contained in Ippeisotsu's short story to reveal hidden meanings and provide new meanings about the Japan-Russia war of 1904-1905 by using the Jacques Derrida's deconstructive reading method. This study also connects the context outside the text, namely the historical context to find the position of the work in the midst of the war situation in 1908. Therefore, Michel Foucault's theory of power regarding discourse is used to see how the discourse related to war, the image of the ideal army, the doctrine of state defense and obedience to the emperor was constructed. Deconstructive reading method will be used to deconstruct the binary opposition found and then describe it by using qualitative descriptive method. The result of this study is there are six binary oppositions found in Ippeisotsu's short story. These six binary oppositions are used to reveal hidden meanings and to give new meaning to the Japan-Russia war of 1904-1905. The six binary oppositions found are superior (Japan) and inferior (China), leader and follower, subject of command and object of command, brave soldier and fearful soldier, physically strong soldier and physically weak soldier, and the last is the battlefield and civilian life. If this binary opposition is related to aspects outside the text, namely connecting literary works with wartime situations, then the result of the meaning that is revealed in Ippeisotsu's short story is a critique of the Japan-Russia war.
\end{abstract}

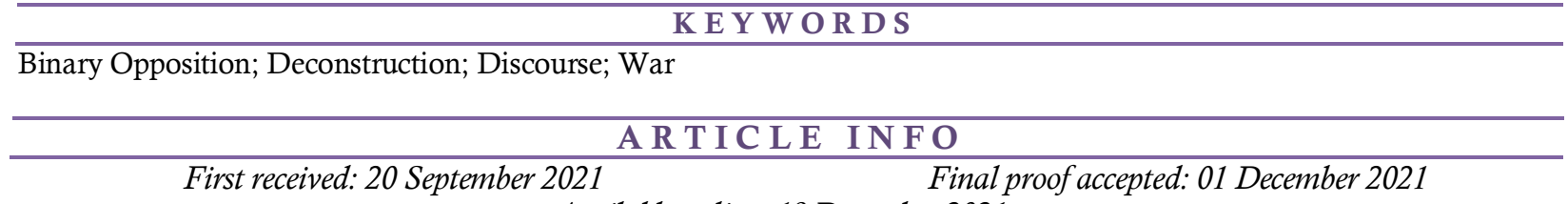

Available online: 19 December 2021

\section{PENDAHULUAN}

Perang merupakan sengketa antara dua negara atau lebih dengan menggunakan kekuatan bersenjata dengan tujuan menguasai lawan dan membangun kondisi 'damai' seperti yang diinginkan pemenang (Oppenheim dalam Sitanggang, 2013). Dewasa ini, perang biasanya dianggap sebagai konflik besar yang terjadi antar negara dengan maksud tertentu. Dalam keadaan konflik yang lebih tinggi, alasan terjadinya perang akan menjadi lebih kompleks. Menurut Lindemann dalam Sulaeman (2017), terdapat empat motivasi utama terjadinya perang, yaitu kebanggaan, antipati (perbedaan identitas yang mencolok), harga diri secara universal, dan harga diri tertentu. Selain 
itu, ada pula alasan yang disebabkan oleh perbedaan ideologi, keinginan menguasai sumber daya alam, dan keinginan untuk memperluas wilayah. Selain itu, perang merupakan salah satu cara penguasa untuk melanggengkan kekuasaan dan pengaruhnya.

Dalam konteks negara, seseorang yang dapat memberikan pengaruh dan dampak pada orang lain adalah kepala negara. Pada era Meiji di Jepang, kaisar merupakan pusat dari segala pengambilan keputusan. Hal ini disebabkan Jepang merupakan negara dengan sistem kekaisaran. Pada era itu juga, militer mempunyai hubungan yang sangat erat dengan kaisar. Hal ini disebabkan pembentukan militer Jepang dibentuk langsung oleh mandat kaisar pada tahun 1868 (Buck, 1971). Dengan kedekatan antara kaisar dan militer negara, penanaman pengaruh dari kaisar kepada para tentara menjadi lebih mudah. Dalam upaya menanamkan nilai keprajuritan terhadap militer, kaisar memberikan titah kepada tentara untuk menghafalkan kode etik Gunjin Chokuyu (The Imperial Rescript to Soldiers and Sailors) (Jowett, 2002 dalam Zafarayana, 2019). Titah tersebut menjadi dasar perilaku yang membuat tentara Jepang untuk senantiasa memberikan kesetiaan mutlak, kesederhanaan, harga diri, keberanian dan disiplin. Melalui titah kaisar tersebut akhirnya semangat untuk melaksanakan perintah Kaisar menjadi meningkat dan menjadi dasar semangat patriotisme tentara Jepang. Kebijakan ini menjadi dasar nasionalisme dan patriotisme pada saat perang Jepang-Rusia.

Perang Jepang-Rusia berlangsung dari tanggal 8 Februari 1904 sampai 5 September 1905. Perang ini adalah perang yang terjadi akibat persaingan imperialistik bangsa Jepang dan Rusia untuk memperebutkan kekuasaan di wilayah Asia Timur, yaitu Manchuria dan Korea. Peristiwa perang Jepang-Rusia tidak hanya tertulis dalam sejarah, tetapi juga diangkat menjadi tema dalam karya sastra.

Katai Tayama (1872-1930) merupakan seorang sastrawan Jepang yang pernah terjun langsung ke medan perang Jepang-Rusia. Tayama ikut dalam peperangan Jepang-Rusia dalam korps angkatan darat kekaisaran Jepang (Imperial Army) selama hampir 6 bulan sebagai koresponden perang untuk penerbit Hakubunkan (Strecher, 2009). Tayama merupakan seorang tokoh sastrawan beraliran naturalis yang menulis I-novel. Tayama juga banyak menulis pengalamannya sewaktu ikut dalam perang Jepang-Rusia. Salah satu karyanya yang mengisahkan cerita dengan latar perang JepangRusia tersebut berjudul Ippeisotsu (Seorang Tentara).

Di dalam cerpen ini, penulis menemukan gagasan menarik. Cerpen ini bertemakan perang, tetapi kebrutalan dan kekerasan tidak ditonjolkan. Dalam cerpen ini, juga diperlihatkan tokoh utama dengan sosok yang lemah karena mengidap penyakit yang bisa merenggut hidupnya kapan saja. Tentara Jepang pada masa perang Jepang-Rusia seharusnya memiliki citra seorang tentara yang berani dan berfisik kuat dengan jiwa bushido-nya yang sangat kuat karena sudah dibekali dengan doktrin-doktrin mengenai nasionalisme dan patriotisme yang didapat dalam wajib militer dan pelatihan spiritual. Terlebih lagi mengingat pada masa perang, pemerintah militer Jepang tengah gencar membangun identitas sebagai negara yang kuat di dunia internasional, khususnya Barat.

Apa yang dikampanyekan oleh pemerintah Jepang mengenai kebaikan perang bahwa perang itu untuk kebaikan rakyat Asia dan keberanian para tentara Jepang yang berani mati bertempur di medan perang untuk kemuliaan kaisar dan kejayaan negaranya, dilakukan untuk mendapatkan dukungan dari masyarakat Jepang terhadap perang yang dilakukan Jepang tersebut. Namun, apa yang dikampanyekan tersebut, didapati berbeda oleh mereka yang pernah dikirim ke medan perang. Sejarawan dan cendekiawan sastra Jepang, Keene (1978) mengutip pernyataan seorang sastrawan Jepang yang dikirim sebagai wartawan ke medan perang, Ishikawa Tatsuzo (1905-1985) yang mendapati kenyataan di medan perang yang berbeda dengan yang diglorifikasi oleh pemerintah Jepang tersebut. Ishikawa mengatakan, "The reports in the Japanese press were all lies. They told us Japan's war was a holy war, that the Japanese soldiers were godlike beings, and that peace and harmony reigned over the territories our forces had occupied. But war cannot possibly be so glorious. It is brutal, miserable, idiotic." Dari pernyataan Ishikawa tersebut, jelas tergambar bagaimana tentara dan akibat dari perang tersebut sangatlah berbeda dengan apa yang dikampanyekan oleh pemerintah Jepang.

Di dalam cerita Ippeisotsu, 'jiwa bushido' yang semestinya dimiliki oleh seorang tentara, sebagaimana yang digaungkan citranya oleh pemerintah Jepang pada masa itu, dalam beberapa adegan mengalami keguncangan. Dari temuan yang telah disebutkan tadi, penulis menangkap ada sebuah gagasan yang mempertanyakan nasionalisme, patriotisme, makna perang, dan citra tentara ideal tentara Jepang di masa perang. Dalam penelitian ini, akan digunakan cerpen Ippeisotsu karya Katai Tayama sebagai objek penelitian.

Di Indonesia sendiri, penulis belum menemukan penelitian yang mengangkat karya Tayama. Karena itu, penulis menganggap penelitian ini dapat berguna untuk menambah pengetahuan mengenai salah satu sastrawan aliran naturalis ternama Jepang dan karyanya yang oleh beberapa peneliti Barat disebut 
menyiratkan anti perang meski selama hidupnya Tayama tidak pernah secara langsung menyatakan bahwa Ia anti terhadap perang yang dilakukan oleh Jepang. Henshall (2015) dalam artikelnya yang berjudul In Search of Nature, menelaah Ippeisotsu dari aspek alam, yakni bagaimana keberadaan tokoh utama sendirian di tengah alam yang luas dan mengancam kematian, menjadi medan tempat tokoh utama menemukan kediriannya. Henshall (2015) menyoroti karya Tayama yang lain yang juga mengangkat aspek alam dan tanggapan tokoh utama terhadap medan yang dihadapi. Berbeda dengan Henshall, penulis akan menelaah Ippeisotsu dengan menggunakan metode pembacaan dekonstruktif untuk mengungkap gagasan menolak perang. Penulis belum menemukan penelitian yang mengupas Ippesotsu dengan metode pembacaan dekonstruktif.

Penulis tertarik untuk menganalisis tentang bagaimana Katai Tayama menggambarkan perang Jepang-Rusia melalui tokoh utama dengan menggunakan metode pembacaan dekonstruktif Jacques Derrida sebagai pisau bedah. Penulis akan melihat tanda-tanda berupa oposisi biner mengenai Jepang, sosok pemimpin, tentara, dan medan perang yang terdapat dalam cerpen. Menurut Emzir dan Rohman (2015), dekonstruksi adalah pikiran yang muncul karena berusaha menolak atau mengkritik sebuah sistem yang sudah terstruktur. Sedangkan Derrida mendefinisikan bahwa dekonstruksi adalah gerak ganda membalikkan dan menetralisasi terhadap pasangan konsep metafisika seperti; suara/tulisan, konsep/metafora, semantik/sintaksis, dan sebagainya (Haryatmoko, 2016). Dari dua definisi di atas, dapat disimpulkan bahwa dekonstruksi adalah pikiran yang muncul untuk menilik dan mengkritisi sebuah sistem metafisika yang terstruktur.

Dekonstruksi berguna untuk membantu melihat apa yang coba disembunyikan oleh sejarah atau yang dilarang melalui unsur-unsur yang tertindas. Penyembunyian makna itu berlangsung melalui hierarki metafisik yang terdapat dalam logika biner (Haryatmoko, 2016). Oleh karena itu, Gagasan dasar dari dekonstruksi ialah ingin menyingkap dan ingin melihat pusat teks beserta strukturnya bila konsep di dalamnya dihilangkan agar oposisi biner tidak lagi berhenti pada sisi kutub yang dianggap sudah menjadi kepastian. Saat sebuah makna ditempatkannya pada hierarkis metafisik yang lebih tinggi, merupakan upaya pembakuan makna yang tidak lain merupakan upaya untuk menetapkan diri dalam posisi otoritas (Haryatmoko, 2016).

Selain metode pembacaan dekonstruktif, teori kekuasaan Michel Foucault mengenai wacana juga akan digunakan untuk melihat bagaimana penanaman doktrin bela negara, wacana kepatuhan pada penguasa, wacana tentara ideal yang berjiwa bushido, dan dukungan terhadap perang dikonstruksi sehingga rakyat mendukung perang dan mengikuti perintah kaisar untuk diterjunkan ke medan perang. Melalui wacana ini akan terlihat bagaimana kekuasaan terjalin hingga terwujud doktrinasi yang sangat kuat dan dipatuhi oleh rakyat dengan cara mendukung perang pada masa perang Jepang-Rusia 1904. Perang Jepang-Rusia merupakan perang yang sangat penting bagi Jepang pada masa itu karena selain untuk memperebutkan wilayah kekuasaan di Cina, juga berperang melawan musuh besarnya, Barat. Perang ini erat kaitannya dengan usaha pemerintah Jepang menunjukkan kekuasaan yang setara dengan Barat dalam hal penguasaan wilayah. Perang Jepang-Rusia tidak lepas dari usaha membangun identitas sebagai bangsa dan negara yang memiliki kekuasaan besar (Wilson, 1999).

Kekuasaan dapat menghasilkan rezim kebenaran tertentu yang disebarkan oleh wacana yang diproduksi oleh kekuasaan. Proses distribusi wacana akan mengakibatkan sebuah rezim menentukan apa yang dianggap benar dan salah, penting dan tidak penting. Wacana (discourse) dan kuasa/pengetahuan (power/knowledge) merupakan konsep yang utama dalam pemikiran Michel Foucault. Wacana yang dipahami sebagai penjelasan, pendefinisian, pengklasifikasian, dan pemikiran tentang orang, pengetahuan, dan sistem abstrak pemikiran tersebut menurutnya tidak lepas dari relasi kekuasaan. Foucault merupakan filsuf yang keahliannya meliputi berbagai bidang seperti filsafat, sejarah, sosiologi, kritik sastra, gender, dan kritik kebudayaan. Kompleksitas permasalahan yang diungkapkan di dalam buku-buku karyanya dipersatukan oleh masalah pokok, yaitu gagasan mengenai kuasa dan pengetahuan, dan bagaimana keduanya bekerja.

Gagasan tersebut ia jelaskan di dalam bukunya yang berjudul Discipline and Punish: "Kekuasaan menciptakan pengetahuan...pengetahuan dan kekuasaan saling mempengaruhi secara langsung satu sama lain" (Lubis, 2012). Menurut Foucault, pengetahuan adalah apa yang dikumpulkan dan diputuskan benar oleh sekelompok orang. Jadi, ada kekuasaan/kekuatan (power) yang menentukan kebenaran. Melalui kekuatan fisik dan mental, minoritas yang kuat dapat memaksakan gagasan mereka tentang apa yang benar pada mayoritas. Jadi, jika mereka dapat meyakinkan banyak orang untuk percaya tentang apa yang mereka katakan, maka itu lebih penting daripada kebenaran itu sendiri.

Bila dikaitkan dengan wacana dalam teori kekuasaan Foucault, perang Jepang-Rusia diterima sebagai sebuah kebenaran sekaligus pengetahuan pada masa itu. Pemerintah Jepang membangun 
legitimasi atas perang tersebut melalui wacana bela negara dan cinta tanah air. Wacana tersebut ditunjukkan dengan keterlibatan dalam perang sebagai bagian dari perwujudan membangun identitas sebagai bangsa dan negara yang kuat.

Tujuan utama dari penelitian ini adalah menjelaskan bagaimana perang Jepang-Rusia 19041905 dimaknai oleh tokoh utama. Selain itu, penelitian ini juga bertujuan untuk membongkar dan menjelaskan gagasan mengenai perang dalam cerpen Ippeisotsu. Oleh karena itu, penelitian ini difokuskan untuk membahas oposisi-oposisi biner dan konteks di luar teks, yaitu sejarah mengenai perang Jepang Rusia (1904-1905) untuk mendekonstruksi makna dari cerpen Ippeisotsu.

\section{METODOLOGI PENELITIAN}

Dalam penelitian ini, jenis penelitian yang digunakan adalah penelitian kualitatif deskriptif. Dalam upaya mendekonstruksi oposisi biner yang ada, metode pembacaan dekonstruksi Jacques Derrida akan digunakan sebagai pisau bedah utama. Sumber data dalam penelitian ini merupakan cerpen Ippeisotsu (Seorang Tentara) Karya Katai Tayama yang diambil dari 田山花袋 一兵卒 'Tayama katai -Ippeisotsu' (aozora.gr.jp).

Analisis penelitian yang penulis lakukan adalah identifikasi, penerapan, dan simpulan (Sugiyono, 2009). Proses identifikasi dilakukan dengan menghimpun tanda-tanda berupa oposisi biner yang diambil dari sudut pandang tokoh utama dan orang ketiga maha tahu. Proses penerapan dilakukan dengan menghubungkan dengan poin yang memuat konstruksi wacana dengan teori kekuasaan Michel Foucault dan membongkar hierarki metafisika dari oposisi biner menggunakan metode pembacaan dekonstruktif Jacques Derrida. Selanjutnya menghubungkan hasil penerapan kepada konteks di luar teks, yaitu sejarah. Kemudian proses terakhir, yaitu simpulan dilakukan dengan menarik kesimpulan berdasarkan hasil dari penelitian.

\section{HASIL DAN PEMBAHASAN}

Berdasarkan proses identifikasi, hasil temuan yang penulis temukan pada cerpen Ippeisotsu Karya Katai Tayama adalah enam buah oposisi biner sebagai penggambaran makna perang yang terjadi pada perang Jepang-Rusia 1904-1905. Keenam Oposisi biner yang ditemukan adalah superior (Jepang) dan inferior (Cina), pemimpin dan pengikut, subjek pemberi perintah dan subjek penerima perintah, tentara pemberani dan tentara gentar, tentara berfisik kuat dan tentara lemah, dan yang terakhir adalah medan perang dan kehidupan sipil.

\section{Superior (Jepang) dan Inferior (Cina)}

Jepang sebagai penguasa (yang menguasai wilayah Cina) dan Cina sebagai pihak yang dikuasai dijadikan sebagai hierarki metafisika karena adanya unsur superior dan inferior yang terdapat pada hubungan keduanya. Cina sebagai pihak inferior terlihat dengan bagaimana mereka diperlakukan sebagai objek yang dilihat-diamati-diawasi, sedangkan si tentara Jepang adalah subjek yang melihat-mengamati-mengawasi. Bahkan dalam penyebutan orang Cina sendiri pun, di dalam teks mereka disebut sebagai "buruh Cina". Hal ini menandakan bahwa jika ada seorang "buruh" maka akan ada seorang "mandor" yang mengawasi pekerjaan-pekerjaan mereka. Hubungan antara mereka yang diawasi dan mengawasi dapat terlihat pada Data 1 berikut ini.

$$
\begin{aligned}
& \text { Data 1: } \\
& \text { 「・・・さっきの汽車がまだあそこにいる。釜の } \\
& \text { ない煙筒のない長い汽車を、支那苦 力が幾百人と } \\
& \text { なく寄ってたかって、ちょうど蟻が大きな獲物を } \\
& \text { 運んでいくように、えっさらおっさら押していく。」 } \\
& \text { “. . Sakki no kisha ga mada asoko ni iru. Kama no nai entō } \\
& \text { no nai nagai kisha o, shina kūrī ga iku hyaku hito to naku }
\end{aligned}
$$

(Tayama, 1908, hal 2)

Orang Cina digambarkan sebagai buruh (支那苦 力' shina kūri') yang sedang mendorong kereta uap seperti pasukan semut yang menggotong makanan. Kereta uap yang dimaksud bukanlah kereta uap untuk transportasi manusia pada zaman sekarang. Namun, merupakan kereta uap yang berisikan pasokan makanan, amunisi, dll untuk kepentingan perang pada masa itu. Hal ini menjelaskan bahwa posisi orang Cina sebagai pihak yang inferior karena mereka menjadi objek yang diawasi dan diperintah oleh mereka dari pihak yang superior, yaitu Jepang. Akan tetapi, melalui potongan paragraf tersebut, tidak terlihat kesuperioran tokoh utama saat melihat orang-orang Cina tersebut. Tidak terlihat pula dia memandang rendah mereka.

Penulis menangkap kesan tokoh utama yang menaruh empati kepada buruh Cina tersebut. Sang tokoh utama lebih terkesan merasa kasihan kepada 
mereka yang harus mendorong kereta uap tersebut, sampai-sampai menggunakan pengandaian sebagai 'semut'. Penulis juga menangkap makna 'semut' tersebut sebagai gerombolan pekerja yang rajin. Namun, harus terbelenggu oleh perintah yang diberikan oleh pemimpin dan hanya bisa mengikuti arahan tersebut, sehingga si orang Cina dianggap sebagai sosok yang teratur karena selalu mengikuti perintah atasannya tanpa bisa mengeluarkan ekspresi yang mereka rasakan.

Narasi cerpen yang memberi pembaca 'kunci' mengenai keberadaan kekuasaan Jepang yang direpresentasikan melalui tokoh utama, dalam narasi cerpen berikutnya memberikan gambaran yang kontras antara gambaran Jepang sebagai pihak yang berkuasa dengan realitas yang dialami oleh tokoh utama sebenarnya. Pada hierarki metafisika Jepang yang lebih superior dibandingkan Cina, terjadi pembalikan oposisi yang menghancurkan hierarki metafisika tersebut seperti terlihat pada Data 2.

Data 2:

「全身の力を絞って呼んだ。聞こえたに相違ないが 振り向いてもみない。どうせ碌なことではないと 知っているのだろう。一時思い止とまったが、また 駆け出した。そして今度はその最後の一 輌によう やく追い着いた。

米の叭が山のように積んである。支那人の爺が振り 向いた。丸顔の厭な顔だ。有無をいわせずその車に 飛び乗った。そして吹と吹との間に身を横たえた。 支那人はしかたがないというふうでウオーウオーと 馬を進めた。ガタガタと車は行く。」

"Zenshin no chikara o shibotte yonda. Kikoeta ni sōinaiga furimuite mo minai. Dōse rokuna kotode wa nai to shitte iru nodarou. Ichiji omoi tome tomattaga, mata kakedashita. Soshite kondo wa sono saigo no ichiryou ni yōyaku oi tsuita. Kome no kamasu ga yama no yō ni tsundearu. Shina jin no ji ga furimuita. Marugao no iyana kaoda. Umu o iwasezu sono kuruma ni tobinotta. Soshite kamasu to kamasu to no ma ni mi o yokotaeta. Shina jin wa shikata ga nai to iu füde uōuō to uma o susumeta. Gatagata to kuruma wa iku."

"Teriakannya dijeritkan dengan sekuat tenaga. Yang di sana sudah pasti mendengar jelas, tapi sedikit pun tidak menoleh. Mungkin mereka pikir itu bukan sesuatu yang terlalu penting. Rasanya dia melihat mereka berhenti sejenak, tapi ternyata kembali melaju. Dia mengejar untuk terakhir kalinya, sampai keretanya berhenti.

Di kereta kuda itu ada tumpukan jerami yang menggunung. Dia melihat si orang Cina membalikkan badan ke arahnya. Wajah bulat yang menunjukkan ketidaksukaan. Tanpa menghiraukan itu, dia melompat ke kereta, kemudian menempatkan dirinya di antara tumpukan tas jerami. Si orang Cina berpikir bahwa tidak ada alasan untuk mengusirnya, jadi dia melajukan kereta dengan kuda-kuda yang meringkih. Kereta mulai berjalan."

(Tayama, 1908, hal 4)
Melalui potongan paragraf Data 2 yang menyebutkan「どうせ碌なことではないと知って いるのだろう。一時思い止とまったが、また駆け 出した。」'Dōse rokuna kotode wa nai to shitte iru nodarou. Ichiji omoi tome tomattaga, mata kakedashita.', "Mungkin mereka pikir itu bukan sesuatu yang terlalu penting. Rasanya dia melihat mereka berhenti sejenak, tapi ternyata kembali melaju" menjelaskan bahwa ada perasaan dari sang tokoh utama bahwa dirinya yang seorang tentara merupakan sosok yang dianggap tidak terlalu penting. Padahal, jika melalui pembacaan hierarki metafisika, tentu saja sosok tentara Jepang memiliki kedudukan yang lebih tinggi dibandingkan orang Cina. Namun, si orang Cina tidak menghiraukannya meskipun sebenarnya dia mendengar panggilan dari sang tokoh utama.

Menurut sejarah, pada saat terjadi perang JepangRusia 1904-1905, Jepang merasa memiliki derajat ras yang lebih tinggi dibandingkan dengan Cina. Hal ini disebabkan oleh propaganda yang dibuat oleh elite Jepang dengan menyebarkan paham superioritas ras Jepang dibandingkan ras lain yang berada di Asia. Selain itu, elite Jepang juga mengembangkan sistem klasifikasi dan hierarki ras, kewarganegaraan, keseragaman bahasa, dan identitas budaya di wilayah kolonial Jepang masa itu, yaitu Taiwan, Korea, dan Manchuria (Fukurai \& Yang, 2017). Melalui wacana hierarki ras ini, Jepang merasa memiliki hak untuk menguasai Cina dan menganggap Cina sebagai pihak yang inferior.

Namun, melalui kacamata dekonstruksi, diperlihatkan orang Cina lebih superior karena telah menghiraukan sang tokoh utama yang pada masa itu memiliki kedudukan lebih tinggi dibandingkan si orang Cina. Di sisi lain, sang tokoh utama menjadi lebih inferior karena keadaannya yang lemah dan memang tidak ada tergambar dalam dirinya untuk mengancam si orang Cina dengan senapan yang dia bawa agar diperbolehkan naik. Selain itu, tidak tergambar pula perlakuan sang tokoh utama yang tidak menyukai orang Cina tersebut.

\section{Pemimpin (Kaisar) dan Pengikut (Rakyat)}

Perang yang dilakukan oleh para tentara pada cerpen Ippeisotsu ini merupakan perang yang mereka persembahkan untuk kekaisaran Jepang. Sosok pemimpin kekaisaran Jepang merupakan sosok yang bertanggung jawab atas bangkit dan berkembangnya rasa nasionalisme dan patriotisme yang dimiliki oleh rakyat Jepang, terutama para tentara yang maju ke medan perang. Bukti bahwa peperangan ini merupakan persembahan rakyat, terutama mereka 
yang menjadi tentara kepada kekaisaran Jepang dapat dilihat pada Data 3 di bawah ini.

Data 3:

「一種の遠いかすかなるとどろき、仔細に聞けばな るほど砲声だ。例の厭な音が頭上を飛ぶのだ。血 汐が流れるのだ。こう思った渠は一種の恐怖と憧憬 とを覚えた。戦友は戦っている。日本帝国のために 血汐を流している。」

"Isshu no tōi kasukanaru todoroki, shisai ni kikeba naruhodo hōseida. Rei no iyana oto ga zujō o tobu noda. Chishio ga nagareru noda. Kō omotta mizo wa isshu no kyōfu to dōkei to o oboeta. Sen'yū wa tatakatte iru. Nihon teikoku no tame ni chishio o nagashite iru."

"Bagaikan air terjun di kejauhan, tembakan dan raungan itu, semakin didengarkan jadi semakin jelas. Salah satunya adalah suara memekakkan yang melintas di atas kepala. Ada darah yang mengalir kemudian. Genangan darah yang seperti ini membuatnya teringat akan satu jenis perpaduan antara ketakutan dan kekaguman. Rekan-rekannya sedang berperang. Darahnya mengalir untuk diabdikan pada kekaisaran Jepang."

(Tayama, 1908, hal 5)

Melalui paragraf tersebut yang menyebutkan 「 戦友は戦っている。日本帝国のために血汐を流し ている。」'Sen'yū wa tatakatte iru. Nihon teikoku no tame ni chishio o nagashite iru', "Rekan-rekannya sedang berperang. Darahnya mengalir untuk diabdikan pada kekaisaran Jepang.", dapat dipahami bahwa tentara Jepang berperang demi membawa kemenangan kepada kekaisaran dan pengabdian diri kepada kaisar sebagai simbol negara. Dengan hadirnya simbol negara yang sangat diagungkan, dapat dipastikan doktrin-doktrin yang ditanamkan berhasil meningkatkan nasionalisme yang dimiliki masyarakat Jepang dan membuat mereka tampak bersatu dalam patriotisme dalam menghadapi berbagai permasalahan besar. Sampai-sampai rela mengorbankan nyawa mereka sendiri demi kebaikan negara.

Penyebaran doktrin-doktrin yang ditanamkan itu tidak hanya terjadi di kalangan tentara saja. Namun juga menjadi bagian dari pendidikan sekolah. Doktrin yang disebarkan kepada rakyat Jepang membuat semua golongan di Jepang merasa bahwa mengabdi kepada negara dan mengikuti segala perintah kaisar merupakan suatu keharusan dan kehormatan terbesar yang mereka dapatkan. Bukti bahwa doktrin sudah tersebar ke rakyat Jepang melalui media pendidikan dapat dilihat dari Data 4 berikut ini.
Data 4:

「・・・出発の時、この身は国に捧げ君に捧げて遺 憾がないと誓った。再びは帰ってくる気はないと、 村の学校で雄々しい演説をした。・・・」

“. . . Shuppatsu no toki, kono mi wa kuni ni sasage kimi ni sasagete ikan ga nai to chikatta. Futatabi wa kaette kuru ki wa nai to, mura no gakkō de ooshī enzetsu o shita. ..."

“. . . Saat berangkat sekolah dulu, sosoknya berjanji akan mengabdi untuk negara dan bersumpah bahwa tidak ada hal yang disesalinya. Dia teringat Ketika ia memberikan sebuah orasi yang gagah berani di sekolah di desa. Dia berseru dia siap mati di medan perang. ..."

(Tayama, 1908, hal 7)

Dari Data 4 tersebut tampak bahwa pada diri tokoh utama, wacana bela negara telah beroperasi dan menjadi doktrin yang menggerakkan tokoh utama. Doktrin tersebut juga kembali diteruskan dan diajarkan ke siswa-siswa yang berada di sekolah. Dengan tertanamnya doktrin-doktrin nasionalisme dan patriotisme mengenai bela negara, bahkan anak kecil usia sekolah pun sampai berani mengatakan tentang perjuangan dan kematian. Selain itu, dengan program menanamkan loyalitas yang dilakukan oleh pemerintah, tentu saja dapat memupuk rasa nasionalisme masyarakat Jepang dengan nasionalisme terhadap negara. Hal itu membuat orang Jepang sadar akan tugasnya sebagai objek yang harus selalu rendah hati di hadapan simbol-simbol negara.

Melalui doktrin-doktrin yang diajarkan tersebut, sifat tentara yang loyal kepada pemerintah mulai terbentuk. Hal tersebut juga terdapat pada monolog yang menceritakan sang tokoh utama yang tetap maju ke medan perang untuk bertemu kelompoknya meskipun dalam keadaan sakit. Seperti yang terdapat pada monolog berikut ini

Data 5:

「・・・病気だ、ご覧の通りの病気で、脚気をわず らっている。鞍山站の先まで行けば隊がいるに相違 ない。・・・」

“. . . Byōkida, goran no tōri no byōki de, kakke o wazuratteiru. Anzantan no saki made ikeba tai ga iru ni sōinai. ..."

"... Aku sedang sakit. Tidakkah kau lihat, aku sedang sakit? Aku sakit beri-beri. Aku harus pergi ke stasiun Anshan untuk menemui kelompokku. ...."

(Tayama, 1908, hal 2)

Melalui monolog yang diucapkan sang tokoh utama tersebut, tampak keinginannya untuk tetap maju ke medan perang, yaitu Anshan untuk menemui kelompoknya. Padahal saat ini sang tokoh utama dalam keadaan yang sangat tidak menguntungkan karena sakit yang dideritanya. Meskipun demikian, sang tokoh utama tetap ingin melanjutkan perjuangannya di medan perang $112 \mid \mathrm{P}$ a g e 
bersama kelompoknya seakan-akan lebih memilih mati di barisan depang dibandingkan di rumah sakit yang ditinggalinya sebelum itu. Sang tokoh utama melakukan hal ini sebagai bentuk kewajibannya sebagai seorang tentara yang harus menyelesaikan atau selalu maju ke medan perang. Hal ini sesuai dengan citra tentara ideal yang ditanamkan kaisar kepada para tentara.

Semenjak zaman Edo (1603-1868), identitas nasional Jepang pada kekaisaran Jepang sudah menekankan kesinambungan sejarah yang panjang dengan menekankan elemen-elemen mitos Jepang. Hal ini juga terjadi pada zaman Meiji. Para elite-elite ideolog dan nasionalis Jepang menciptakan narasi "sejarah" bangsa yang berkaitan dengan "zaman para dewa" dan Dewa Matahari Amaterasu sebagai nenek moyang paling awal dari kekaisaran yang berkuasa. Dengan Amaterasu sebagai pemimpin kekaisaran pertama, muncullah narasi mengenai "garis kekaisaran yang tidak terputus" (bansei ikkei). Hal ini juga menjelaskan tentang munculnya agama Shinto di Jepang. Dengan digabungkannya aspek sejarah dan religi tersebut, memunculkan wacana nasional Jepang terhadap kaisar sebagai keturunan dewa dan hal ini menjadi elemen nasional serta karakter religius yang kuat pada orang Jepang (Saaler, 2016).

Melalui sudut pandang kekuatan wacana yang dicetuskan oleh Foucault, tampak di sini bagaimana wacana mengenai nasionalisme dan identitas sebagai bangsa Jepang, serta kaisar sebagai pemimpin yang titahnya harus dipatuhi telah ditanamkan melalui gagasan yang menjadi doktrin sekaligus ideologi. Posisi rakyat sebagai pengikut bukan hanya merupakan keinginan mereka yang semata-mata merasa kaisar merupakan orang yang tepat untuk diikuti. Namun, ada doktrin-doktrin yang diajarkan kepada rakyat dari mereka kecil, sehingga membuat mereka tanpa sadar merasa bahwa mengikuti kaisar sebagai pemimpin merupakan hal yang paling tepat. Dengan demikian muncullah hierarki metafisika yang terkait dengan kaisar dan rakyat, yaitu kaisar sebagai subjek yang memberikan perintah dan rakyat sebagai objek penerima perintah.

\section{Subjek Pemberi Perintah dan Objek Penerima Perintah}

Pada subbab sebelumnya sudah menjelaskan bagaimana hubungan antara kaisar dan rakyat yang merupakan hubungan pemimpin dan pengikut, berkembang menjadi memerintah dan diperintah. Pada cerpen Ippeisotsu, terdapat beberapa paragraf yang menerangkan bahwa perintah atau peraturan yang dibuat oleh kaisar dan pemerintah akan selalu diikuti oleh para tentara. Tentara sebagai objek yang diperintah tanpa mencoba memahami apakah perintah atau peraturan tersebut membawa kebaikan atau tidak, akan tetap melaksanakannya dengan patuh. Salah satu contoh terdapat pada Data 6 berikut ini.

Data 6:
「さっきの下士があそこに乗っている。あの一段高
い米の叭の積み荷の上に突っ立っているのが 彼奴
だ。苦しくつてとても歩けんから、鞍山站まで乗せ
ていってくれと頼んだ。すると彼奴め、兵を乗せる
車ではない、歩兵が車に乗るという法があるかとど
なった。」
"Sakki no kashiga asoko ni notte iru. Ano ichidan takai kome
no kamasu no tsumini no ue ni tsuttatte iru no ga kyatsuda.
Kurushikutte totemo arukenkara, anzantan made nosete itte
kure to tanonda. Suruto kyatsume, hei o noseru kuruma
dewanai, hohei ga kurumaninoru to iu ho ga aru ka to
donatta."
"Dia melihat satu orang petugas yang berdiri di atas
tumpukan tas jerami. Orang itu baru saja naik ke kereta.
Dia yang kesulitan berjalan karena sakit di kakinya,
meminta untuk ikut naik sampai ke Stasiun Anshan.
Tetapi, petugas itu berkata, "ini bukan kendaraan
untuk tentara dan aku tidak tahu apakah ada undang-
undang yang mengatur tentang tentara boleh menaiki
kereta ini."

(Tayama, 1908, hal 2)

Pada kutipan 「すると彼奴め、兵を乗せる車で はない、歩兵が車に乗るという法があるかとどな った。」'Suruto kyatsume, hei o noseru kuruma dewanai, hohei ga kurumaninoru to iu hō ga aru ka to donatta.', "ini bukan kendaraan untuk tentara dan aku tidak tahu apakah ada undang-undang yang mengatur tentang tentara boleh menaiki kereta ini."dapat disimpulkan bahwa terdapat peraturan yang menjelaskan bahwa tentara tidak boleh menaiki kereta dan dimengerti oleh semua orang. Meskipun dalam keadaan sakit yang diderita sang tokoh utama, peraturan tersebut tetap tidak bisa dilanggar. Mereka yang menjalankannya pun tidak bisa protes atau melakukan apa pun.

Selain peraturan mengenai penumpang kereta. Peraturan wajib militer yang diberikan kaisar juga menjadi permasalahan bagi rakyat. Saat berada di medan perang, tidak semua orang yang berada di sana benar-benar ingin membela negaranya sampai harus mengorbankan nyawa. Banyak dari mereka yang tidak bisa atau tidak berani pergi dari medan perang karena sanksi yang harus ditanggung jika melakukannya. Seperti yang terdapat pada Data 7 berikut. 
Data 7:

「かれは疲労と病気と恐怖とに襲われて、いかにし てこの恐ろしい災厄を遁るべきかを考えた。脱走？ それもいい、けれど捕えられた暁には、この上もな い污名をこうむつたうえに同じく死！・・・」

"Kare wa hirō to byōki to kyōfu to ni osowa rete, ikani shite kono osoroshi saiyaku o nogarubeki ka o kangaeta. Dassō? Sore mo ii, keredo torae rareta akatsuki ni wa, kono ue mo nai omei o kōmutta ue ni onajiku shi! . . ."

"Diserang dengan kelelahan dan penyakit dan kematian, dia kerap memikirkan cara untuk bisa kabur dari satu wabah yang mengerikan ini. Melarikan diri? Bisa saja, tapi ketika nanti tertangkap di siang hari, akan timbul aib dan pelecehan. Kalau sudah begitu, sama saja dengan mati! ..."

(Tayama, 1908, hal 8)

Melalui kutipan 「脱走?それもいい、けれど 捕えられた暁には、この上もない污名をこうむつ たうえに同じく死！」’Dassō? Sore mo ii, keredo torae rareta akatsuki ni wa, kono ue mo nai omei o kōmutta ue ni onajiku shi!', "Melarikan diri? Bisa saja, tapi ketika nanti tertangkap di siang hari, akan timbul aib dan pelecehan. Kalau sudah begitu, sama saja dengan mati!" dapat dipahami bahwa melarikan diri dari medan perang merupakan sebuah aib yang dapat mencoreng nama baik mereka. Hal ini juga sesuai dengan nilai-nilai bushido yang diajarkan kepada para tentara saat melakukan wajib militer. Suharman (2012) menyebutkan bahwa, secara umum nilai-nilai bushido adalah keberanian, ketabahan hati, kemurnian, cinta nama baik, kesetiaan, tanggung jawab, rasa malu, dan kehormatan. Nilai bushido yang terkandung dalam kutipan tersebut merupakan nilai keberanian, cinta nama baik, rasa malu, dan kehormatan. Artinya jika tentara kabur dari medan perang, mereka akan dicap oleh masyarakat sebagai sosok yang pengecut. Selain itu, nama baik dan kehormatannya pun akan otomatis hancur.

Hal seperti ini sesuai dengan fakta di yang terjadi pada sejarah, beberapa surat kabar mengekspresikan simpati kepada para tentara yang harus melakukan wajib militer karena sudah dipaksa untuk pergi dari rumah dan berperang untuk negara meskipun bertentangan dengan keinginan mereka. Bahkan ada sebagian kecil dari tentara yang melarikan diri saat dimobilisasi ke medan perang dengan melakukan tindakan yang terbilang ekstrem dengan cara meninggalkan pasukannya, berbuat tindakan kriminal, sampai melakukan bunuh diri (Shimazu, 2008).

Menurut sudut pandang dekonstruksi dalam cerpen Ippeisotsu ini, posisi rakyat sebagai subjek yang harus selalu mengikuti perintah kaisar sebagai kepala negara yang memiliki suara mutlak, tidak sepenuhnya terjadi. Karena banyak dari mereka yang terpaksa melakukan perintah tersebut. Bahkan banyak pula dari mereka yang memang ingin pergi dari medan perang dan tidak menjalankan perintah kaisar. Namun, seperti yang dijelaskan oleh sang tokoh utama, jika melarikan diri dari medan perang, yang menunggu para tentara adalah aib dan pelecehan. Melalui perspektif ini, rakyat tidak sepenuhnya menjadi objek yang menerima segala perintah yang diberikan oleh kaisar. Namun, jika perintah kaisar tidak dituruti, akan mendatangkan petaka bagi mereka dan keluarga.

\section{Tentara Pemberani dan Tentara Gentar}

Pada saat keadaan perang, tentu diperlukan sosok tentara yang gagah berani membela bangsanya. Tidak terkecuali Jepang pada saat perang JepangRusia 1904-1905. Tentara Jepang masa itu haruslah merupakan tentara ideal yang memegang teguh nilainilai bushido dan mengamalkannya, sehingga jiwa bushido yang dimilikinya menjadi kuat. Dalam cerpen Ippeisotsu, citra tentara ideal yang patriotik dan berani tergambar pada Data 8 di bawah ini.

Data 8:
「・・・金州の戦場では、機関銃の死の叫びのただ
中を地に伏しつつ、勇ま進んだ。戦友の血に 塗れ
た姿に胸を撲ったこともないではないが、これも国
のためだ、名誉だと思った。・・・」
“. . . Kinshū no senjōde wa, kikanjū no shi no sakebi no
tadanaka o chi ni fushitsutsu, Isamu ma susunda. Senyū no
chi ni mamireta sugata ni mune o utta koto mo naide wa
naiga, kore mo kuni no tameda, meiyoda to omotta. ...”
“... Di pertempuran Nanshan, dia maju ke garis depan
dengan berani, tiarap di tengah suara tembakan dan
jeritan maut. Ini tidak seperti dia yang belum pernah
merasakan sakit di dada karena dikelilingi tubuh rekan
yang berlumuran darah, tapi dia merasa terhormat
karena ini dilakukan untuk negaranya. ...”

(Tayama, 1908, hal 8)

Melalui penggambaran tersebut, dapat tercipta citra yang menyatakan bahwa tentara-tentara Jepang di medan perang memiliki keberanian dan disiplin yang tinggi kepada negara berkat pelatihan mereka pada saat wajib militer. Pada saat era Meiji, seorang tentara Jepang haruslah memiliki jiwa bushido yang kuat. Jiwa bushido tidak hanya tampak pada fisik seorang tentara, tetapi juga dengan mental yang kuat. Dari kutipan tersebut, pembaca akan diyakinkan bahwa tentara tersebut mencerminkan jiwa bertarung seorang tentara Jepang yang gagah berani. Makna yang muncul adalah tokoh utama seorang tentara yang menghayati dan melaksanakan jiwa bushido yang berperang demi kemuliaan negara dan pemimpinnya, kaisar. Namun, makna tersebut ditantang dalam narasi cerpen yang muncul 
berikutnya. Dalam salah satu monolog yang dilakukan tokoh utama, tergambar citra yang tidak sesuai dengan citra ideal sosok tentara Jepang pada masa itu.

\begin{abstract}
Data 9:
「神がこの世にいますなら、どうか救けてくださ い、どうか遁路を教えてください。これからはどん な難儀もする！どんな善事も寸る！どんなことに も背かぬ。渠はおいおい声を挙げて泣き出した。」 "Kami ga konoyo ni imasunara, dōka tasukete kudasai, dō ka nigemichi o oshietekudasai. Korekara wa donna nangi mo suru! Donna zenji mo suru! Donna kotoni mo somukanu. Mizo wa oioi koe o agete naki dashita."

"Jika memang Tuhan ada di dunia ini, tolonglah aku, tolong tunjukkan jalan untuk aku keluar dari tempat ini. Sekarang dan seterusnya, semua kesusahan akan aku jalani! Segala hal baik akan aku lakukan! Tidak akan lagi aku protes tentang apapun.

Dia menangis menjadi-jadi."
\end{abstract}

(Tayama, 1908, hal 8)

Data 9 menggambarkan sosok seorang tentara sakit-sakitan yang kabur dari rumah sakit untuk menemui teman-temannya di medan perang untuk tetap melanjutkan perjuangannya, berbalik menjadi seorang tentara yang gentar dan ingin pergi dari medan perang. Bahkan sampai menangis dan berdoa kepada Tuhan untuk melakukan apapun asalkan doanya untuk keluar dari medan perang dapat terkabulkan.

Pada masa perang Sino-Russo-Japanese (18941905), pemerintah dan media masa Jepang, membuat perang divisualkan di berbagai visual media seperti, majalah bergambar, foto, film, dll yang membuat perang lebih mudah diakses oleh masyarakat Jepang. Dengan sarana budaya visual untuk menyebarkan gambar-gambar perang, membuat para tentara dan angkatan laut tampak memiliki citra yang jantan dan lebih patriotik di mata masyarakat. Meskipun demikian, pemerintah dan media bekerja sama untuk menciptakan citra perang yang tidak kritis, sehingga memperlebar jarak antara "perang yang baik" yang diciptakan oleh mereka dengan realitas tragis pengalaman perang yang dialami mereka yang berperang (Shimazu, 2008). Hal ini merupakan salah satu wacana maskulinitas tentara Jepang yang dibuat pemerintah melalui nilainilai yang terdapat pada bushido. Secara garis besar, tentara Jepang masa perang harus selalu mematuhi perintah yang diberikan atasannya, harus bersikap kuat, berani dan tidak takut mati dalam keadaan apa pun.

Melalui dekonstruksi, pada masa perang JepangRusia 1904-1905, penggambaran tokoh tentara Jepang yang takut dan tidak ideal merupakan suatu hal yang tidak bisa diterima. Citra yang seperti ini akan memperburuk wacana pemerintah mengenai maskulinitas seorang tentara. Selain itu, bisa juga berdampak pada masyarakat Jepang yang membaca cerita semacam ini dan menyadarkan mereka bahwa "perang tidak sebaik itu". Namun, di sisi lain tergambar pula bahwa di medan peran tidak hanya terdapat mereka yang berani mati, tetapi ada juga orang-orang yang gentar kehilangan nyawanya dan ingin hidup lebih lama lagi.

\section{Tentara Berfisik Kuat dan Tentara Berfisik Lemah}

Pada subbab sebelumnya telah dijelaskan sosok tentara pemberani dan tentara gentar, sedangkan dalam subbab ini akan dijelaskan sosok tentara melalui perspektif dan stereotip yang terdapat pada masyarakat. Salah satu perspektif tersebut adalah bahwa seorang tentara harus memiliki badan yang kuat. Perspektif tersebut dibuktikan dengan percakapan antara sang tokoh utama dengan seorang petugas kereta api pada Data 10.

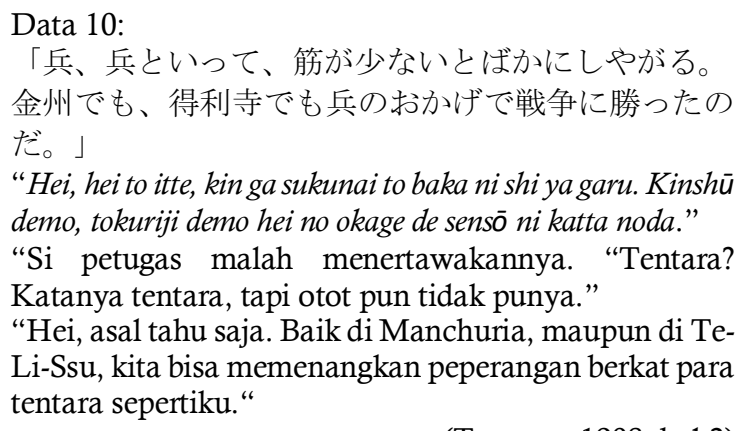

(Tayama, 1908, hal 2)

Dari percakapan tersebut dapat disimpulkan bahwa citra seorang tentara yang terdapat pada masyarakat Jepang merupakan citra seorang tentara yang berbadan kuat dan memiliki otot. Meskipun demikian, dalam cerpen Ippeisotsu justru tokoh utama digambarkan dengan citra seorang tentara yang memiliki fisik lemah. Keadaan lemah yang dialami sang tokoh utama diakibatkan sakit beri-beri yang dideritanya. Hal tersebut dapat dilihat dari Data 11 berikut.

\footnotetext{
Data 11:

「脚が重い、けだるい、胸がむかつく。大石橋から 十里、二日の路、夜露、悪寒、確かに持病の脚気が 昂進したのだ。流行腸胃熱は治ったが、急性の脚 気が襲ってきたのだ。脚気衝心の恐ろしいことを自 覚してかれは戦慄した。どうしても免れることがで きぬのかと思った。と、いても立ってもいられなく なって、体がしびれて脚がすくんだーーおいおい泣 きながら歩く。」
} 
"Ashi ga omoi, kedarui, mune ga mukatsuku. Ōishibashi kara Jüri, futsuka no michi, yotsuyu, okan, tashikani jibyō no kakke ga kōshin shita noda. Ryūkō chōi netsu wa naotta ga, kyūsei no kakke ga osotte kita noda. Kakkeshōshin no osoroshī koto o jikaku shite kare wa senritsu shita. Dōshitemo manugareru koto ga dekinu no ka to omotta. To, ite mo tatte mo irarenaku natte, karada ga shibirete ashi ga sukunda -oioi nakinagara aruku."

"Kaki yang berat, badan yang lesu, dan dada yang penuh sesak. Empat puluh kilometer dari Dashiqiao, dua hari di jalanan, embun malam, menggigil, dan tentu saja penyakit beri-beri yang semakin parah. Flu perutnya sudah sembuh, tapi beri-beri menyerang. Dia yang menyadari bahayanya penyakit beri-beri, kemudian bergidik ngeri. Bertanya-tanya dalam hati, apakah tidak bisa melarikan diri sama sekali. Tidak bisa berdiri, tubuh mati rasa, dan kaki tidak bisa digerakkan — dia berjalan sambil menangisi keadaan."

(Tayama, 1908, hal 8)

Seperti yang tergambar pada paragraf tersebut, sosok seorang tentara sakit-sakitan yang terus melanjutkan perjalanannya, terus menerus berjalan meskipun kakinya terasa berat, badannya terasa lesu dan dadanya pun terasa sesak. Hal ini menggambarkan bahwa tentara di medan perang bukan hanya sosok yang memiliki 'otot' dan berbadan kuat saja. Ada juga sosok tentara yang berfisik lemah karena memiliki penyakit fisik maupun mental di dalam tubuhnya yang tetap melanjutkan perjuangannya demi negara.

Di dalam sejarah, perang Jepang-Rusia 19041905 mengakibatkan meroketnya perbuatan yang kurang baik yang dilakukan oleh tentara. Banyak dari aksi "gila" yang dilakukan para tentara yang datang dari masyarakat bawah dipicu oleh tekanan psikologis saat mereka dimobilisasi ke medan perang. Kisah-kisah perbuatan yang tidak baik ini dengan mudahnya direpresentasikan oleh negara dan media masa sebagai tindakan patriotisme yang dilakukan seorang tentara wajib militer yang rela mengorbankan diri dan keluarganya demi mengabdi pada negara (Shimazu, 2008).

Melalui kacamata dekonstruksi, tentara yang memiliki citra yang lemah dan tidak berdaya bahkan sampai diolok-olok oleh petugas kereta api dan berjuang keras dengan penyakit yang dideritanya, ternyata juga memperjuangkan kemenangan untuk kepentingan negaranya. Hal ini menggambarkan bahwa tentara yang berada di medan perang ternyata bukan hanya sosok yang memiliki fisik dan mental kuat saja, tetapi ada juga tentara yang memperjuangkan negaranya meskipun dalam kondisi yang tidak menguntungkan.

\section{Medan Perang dan Kehidupan Sipil}

Medan perang merupakan tempat di mana perang antara dua kubu atau lebih terjadi. Medan perang biasanya digambarkan dengan suasana yang mencekam, mengerikan, dan membawa ketakutan bagi siapa pun yang bertempur di dalamnya. Selain itu, medan perang juga biasa digambarkan dengan hancurnya bangunan-bangunan, persawahan, jalanan, dll. Keadaan medan perang pada cerpen Ippeisotsu digambarkan seperti pada Data 12 berikut.

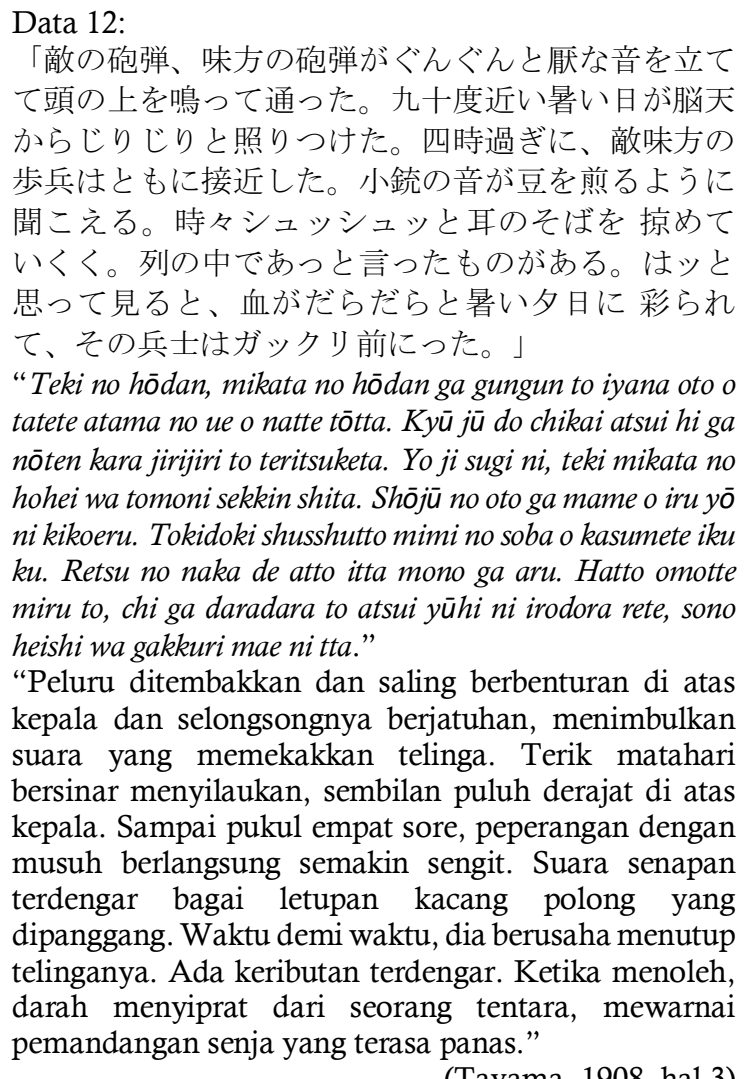

(Tayama, 1908, hal 3)

Seperti yang tergambar pada paragraf tersebut, suasana medan perang yang tergambar pada cerpen Ippeisotsu sangatlah mencekam. Suara tembakan yang bersahut-sahutan, panasnya matahari menemani di atas kepala, hingga puncak ketegangan di mana rekan seperjuangan tokoh utama mati karena tertembak. Meskipun demikian, tidak ada yang bisa mereka lakukan selain maju dan mempersembahkan segalanya kepada negara. Perang dilakukan demi kehormatan dan kemuliaan negara dan pemimpin, sebagaimana yang digambarkan dalam Data 13 berikut. 
Data 13:

「・・・金州の戦場では、機関銃の死の叫びのただ 中を地に伏しつつ、勇ま進んだ。戦友の血に 塗れ た姿に胸を撲ったこともないではないが、これも国 のためだ、名誉だと思った。・・・」

“. . . Kinshū no senjōde wa, kikanjū no shi no sakebi no tadanaka o chi ni fushitsutsu, Isamu ma susunda. Senyū no chi ni mamireta sugata ni mune o utta koto mo naide wa naiga, kore mo kuni no tameda, meiyoda to omotta. . . ."

". . . Di pertempuran Nanshan, dia maju ke garis depan dengan berani, tiarap di tengah suara tembakan dan jeritan maut. Ini tidak seperti dia yang belum pernah merasakan sakit di dada karena dikelilingi tubuh rekan yang berlumuran darah, tapi dia merasa terhormat karena ini dilakukan untuk negaranya. ..."

(Tayama, 1908, hal 8)

Pada era Meiji, seperti yang sudah dibahas pada subbab sebelumnya, perang ini terjadi demi kemenangan kekaisaran. Kaisar menjadi tokoh utama dalam berkembangnya sifat nasionalisme dan patriotisme di Jepang dengan membuat kebijakan wajib militer dan spiritual militer. Mereka yang ikut wajib militer merupakan laki-laki berusia 20-an dan harus meninggalkan keluarganya demi membela negara. Dari kutipan tersebut, bagi pembaca, makna mengenai perang terbangun dan ditangkap sebagai suatu jalan untuk menunjukkan kehormatan dan kemuliaan negara dan pemimpin. Tokoh utama yang merupakan seorang tentara, dari kutipan tersebut, terpanggil untuk memenuhi panggilan tugas (義務 ' gimu') dan menjadi bagian dari tugas terhormat tersebut. Tokoh utama melakukan tugas yang ditanamkan sebagai kewajiban seorang rakyat bagi pemimpinnya.

Namun, makna yang ditangkap dalam narasi berikutnya tampak tidak konsisten dengan makna yang telah terbentuk sebelumnya. Realitas yang lain mengenai sosok seorang tentara yang gagah berani dan berani mati, didapati berbeda dalam narasi cerpen berikutnya. Kenyataannya tidak semua yang mengikuti wajib militer memang ingin meninggalkan keluarganya di desa dan benar-benar ingin berada di medan perang. Hal tersebut dibuktikan dengan potongan paragraf pada Data 14 .

Data 14:

「忽然最愛の妻の顔が眼に浮かぶ。それは門出の時 の泣き顔ではなく、どうした場合であったか忘れた が心からかわいいと思った時の美しい笑い顔だ。母 親がお前もうお起きよ、学校が遅くなるよと摇り起 こす。かれの頭はいつか子供の時代に飛び返ってい る。・・・

"Kotsuzen saiai no tsuma no kao ga me ni ukabu. Sore wa kadode no toki no nakigaode wa naku, dōshita baaideatta ka wasuretaga kokorokara kawaī to omotta toki no utsukushī warai gaoda. Hahaoya ga omae mō o okiyo, gakkō ga osoku naru yo to yuriokosu. Kare no atama wa itsuka kodomo no jidai ni tobi kaetteiru. ..."

"Tiba-tiba, wajah istri tersayang terbesit di benaknya. Wajah yang muncul bukanlah wajah yang menangis sedih, melainkan wajah yang-dia lupa apa sebabnyatersenyum manis, dan dari dasar lubuk hatinya ia memuji keindahan paras istrinya kala itu. Ibunya membangunkan, sambil berkata agar segera bangun kalau tidak ingin terlambat pergi ke sekolah. Entah kenapa ingatannya melompat kembali ke masa kecil. ..."

(Tayama, 1908, hal 2)

Kehidupan sipil bisa dianggap sebagai kehidupan yang kita jalani dengan damai pada hari ini. Biasanya digambarkan dengan suasana hiruk-pikuk perkotaan, perdagangan, hangatnya berkumpul bersama keluarga, dll. Secara garis besar, merupakan kehidupan yang damai tanpa ada konflik bersenjata di sekitarnya. Melalui potongan paragraf Data 14 ini, sosok tentara yang berada di medan perang dan sedang sakit-sakitan merasa ingin kembali ke masa di mana ia bisa bertemu dengan istri dan keluarganya tanpa harus menjalani kehidupan perang di mana dia harus siap sedia mengorbankan nyawanya demi negara. Selain itu, terdapat pula paragraf yang menerangkan mengenai kehidupan sipil pada Data 15 berikut.

\footnotetext{
Data 15 :

「草叢には虫の声がする。故郷の野で聞く虫の声と

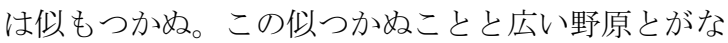
んとなくその胸を痛めた。一時とだえた追懷の情が 流るるように漲ってきた。」

"Kusamura ni wa mushi no koe ga suru. Kokyou no no de kiku mushi no koe to wa ni mo tsukanu. Kono nitsukanu koto to hiroi nohara to ga nantonaku sono mune o itameta. Ichiji todaeta tsuikai no jō ga nagareruru yō ni minagitte kita."

"Suara serangga terdengar dari rerumputan. Suaranya tidak mirip dengan suara serangga yang biasa didengarnya di kampung halaman. Ketidaksamaan di hamparan yang luas ini, entah kenapa menciptakan rasa sakit di dada. Dia berhenti sejenak untuk merasakan emosi terkumpul dan mengalir di dalam tubuh."
}

(Tayama, 1908, hal 7)

Melalui kutipan mengenai serangga yang berbunyi 「故郷の野で聞く虫の声とは似もつかぬ - 」 'Kokyou no no de kiku mushi no koe to wa ni mo tsukanu', "Suaranya tidak mirip dengan suara serangga yang biasa didengarnya di kampung halaman" tersebut menjelaskan memori kerinduan yang mendalam akan kampung halamannya. Hal ini bisa disimpulkan melalui kepekaan sang tokoh utama untuk menangkap hal-hal kecil seperti suara serangga di medan perang dengan serangga di kampung halamannya. Memorinya tentang 
kampung halaman yang berbeda dengan medan perang inilah yang membuatnya semakin merasakan kesengsaraan dan medan perang tidak lagi menjadi medan untuk menunjukkan keberanian yang ia orasikan dengan gagah berani di bangku sekolah.

Yoneyama dalam Purba (2015) menyatakan bahwa, memori mengacu pada pengetahuan asli dan autentik yang dimiliki oleh seseorang dan dikaitkan dengan hal subjektif, seperti kerinduan, kenangan nostalgia, kesetiaan, dan pengabdian. Hal ini berbeda dengan sejarah yang merupakan produk dari kekuasaan. Melalui memori dan proses mengenang, akan terjalin lebih banyak kehadiran hal yang menjadi pengingat sebagai bentuk keinginan atau sebaliknya penolakan tentang peristiwa masa lalu yang terjadi. Dari kutipan Data 15 tersebut, memori yang bangkit tentang kampung halaman, dan perasaan terhadap suara serangga yang berbeda, dapat disimpulkan sebagai bentuk keinginan tokoh utama untuk menjauhi medan perang. Medan perang menjadi tempat yang dirasa berjarak dan ingin dijauhi. Hal ini berbeda dengan di awal cerita ketika tokoh utama ingin menyusul rekan-rekannya di garis depan pertempuran meski ia sedang sakit, kali ini kampung halaman dengan suara jangkrik yang dikenang tokoh utama, menjadi tempat yang ingin didekati atau dengan kata lain menjadi kehidupan yang lebih dicita-citakan oleh tokoh utama.

Dengan menggunakan kacamata dekonstruksi, hierarki oposisi yang merupakan medan perang, dilakukan pembalikan hierarki oposisi. Medan perang yang seharusnya digambarkan lebih banyak karena merupakan cerpen bertemakan perang malah tidak muncul terlalu banyak. Di sisi lain, penggambaran akan kehidupan sipil dan masa lalu sang tokoh utama lah yang menjadi sorotan latar utama pada cerpen Ippeisotsu. Hal ini bisa disimpulkan bahwa dekonstruksi berjalan dengan dasar keinginan untuk hidup di kehidupan yang ideal. Kehidupan ideal yang tokoh utama inginkan merupakan kehidupan sipil yang damai, penuh cinta, dan dapat berkumpul kembali dengan keluarga di kampung halaman. Bukan kehidupan sebagai tentara pemberani yang berani mati di medan perang demi kehormatan sebagai bentuk nilai-nilai yang tertanam pada bushido.

\section{SIMPULAN}

Berdasarkan pembahasan dan penelitian yang telah dilakukan oleh penulis, dapat disimpulkan bahwa Katai Tayama melalui tokoh utama memberikan pemaknaan baru mengenai perang Jepang-Rusia 1904-1905 dalam cerpennya yang berjudul Ippeisotsu.
Pemberian makna baru tersebut tertuang dalam enam oposisi biner yaitu, Jepang sebagai posisi superior dan Cina sebagai posisi yang inferior, pemimpin dan pengikut, subjek pemberi perintah dan subjek penerima perintah, tentara pemberani dan tentara gentar, tentara berbadan kuat dan tentara sakit-sakitan, dan yang terakhir adalah medan perang dan kehidupan sipil.

Melalui bukti-bukti di atas, penulis menyimpulkan bahwa Katai Tayama dengan sengaja tidak membuat gambaran tentara Jepang yang berani mati dan siap membunuh lawan. Ia malah lebih menceritakan sosok tentara yang sakit-sakitan dan berfisik lemah. Hal ini tentu berkebalikan dengan citra tentara Jepang di masa perang yang diglorifikasi dengan ketangguhan mental dan fisik bertempur di medan perang. Tentara dalam cerpen ini digambarkan memiliki pandangan yang tidak melihat rakyat Cina sebagai objek yang inferior. Di masa perang, wacana hierarki ras di mana Jepang sebagai ras yang lebih tinggi dari Cina ditanamkan dengan kuat sebagai upaya melegitimasi aksi menduduki wilayah Asia. Tayama tidak membuat medan perang yang mengerikan dan berdarah-darah. Kehidupan sipil bersama keluarga dan cinta menjadi bayangan tokoh utama di masa perang. Ia didominasi oleh perasaan untuk hidup dengan rasa cinta, bukan dengan perasaan berani mati di medan tempur. Selain itu, dengan membuat tokoh utama sebagai orang yang sakit-sakitan, membuka pemaknaan baru akan citra tentara Jepang pada masa perang. Melalui pembalikan hierarki menggunakan teori Jacques Derrida pada medan dalam cerpen Ippeisotsu, membuat makna baru mengenai perang, yaitu perang bukanlah medan untuk mengglorifikasi kekuatan militer dan kekuatan fisik seorang tentara. Tokoh utama lebih mendambakan kehidupan sipil yang damai tanpa pertumpahan darah. Kehidupan sipil yang damai tanpa pertumpahan darah ini diungkapkan secara tersirat karena pada masa perang Jepang-Rusia 1904-1905, hal-hal seperti ini tidak bisa diungkapkan secara gamblang ke masyarakat karena bertentangan dengan wacana nasionalisme yang tengah diserukan oleh pemerintah Jepang untuk menggerakkan rakyat Jepang mendukung aksi perang.

\section{REFERENSI}

Buck, J. H. (1971). Education and Socialization in the Japanese Self-Defense Force. Georgia University.

Diakses dari http://www.jstor.com/stable/2384256

Emzir, E., \& Rohman, S. (2015). Teori dan Pengajaran Sastra. Jakarta: Raja Grafindo Persada. 
Fukurai, H., \& Yang, A. (2017). The History of Japanese Racism, Japanese American Redress, and the Dangers Associated with Government Regulation of Hate Speech. Hastings Const. LQ, 45(3). Diakses dari https://repository.uchastings.edu/cgi/viewcontent.cg i? article $=2064 \&$ context $=$ hastings constitutional law quaterly

Haryatmoko, H. (2016a). Critical Discourse Analysis (Analisis Wacana Kritis): Landasan Teori, Metodologi dan Penerapan. Jakarta: Rajawali Pers.

Haryatmoko, H. (2016b). Membongkar Rezim Kepastian. Yogyakarta: PT Kanisius.

Henshall, K.G. (2015). In search of nature: The Japanese writer Tayama Katai (1872-1930), The Journal of Japanese Studies, 41(2):410-412. DOI:10.1353/jjs.2015.0058

Keene, D. (1978). The barren years. Japanese war literature. Monumenta Nipponica, 33(1), 67-112. Tokyo: Sophia University.

Lubis, A. Y. (2012). Teori dan Metodologi Ilmu Pengetahuan. Jakarta: Rajawali Press.

Purba, E.R. (2015, November). Memory, time, and space, in several Japanese atomic-bomb poems. Dipresentasikan pada Litcri '15 Iv. Literary Criticism Conference. Diakses dari https://www.academia.edu/39151698/LITCRI 15 IV LITERARY CRITICISM CONFERENCE P ROCEEDINGS

Saaler, S. (2016). Nationalism and history in contemporary Japan. The Asia-Pasific Journal, 14(7). Diakses dari https://apjif.org/2016/20/Saaler.html

Shimazu, N. (2008). Patriotic and despondent: Japanese society at war, 1904-5. The Russian Review, 67(1), 34-49. Diakses dari http://www.jstor.org/stable/ $\underline{20620669}$
Sitanggang, D. (2013). Pengrusakan tempat bersejarah dalam perang antarnegara sebagai pelanggaran hukum humaniter internasional. Lex et Societatis, 1(2). Diakses dari https://ejournal.unsrat.ac.id/index.php/lexetsoci etats/article/view/1745

Strecher, M. C. (2009). From Kawaraban to reportage: toward a theory for Japanese literary journalism. 立命 館国際研究，21(3), 491-507. Diakses dari https://d1.ndl.go.jp/info:ndljp/pid/8313472

Sugiyono, S. 2009. Metode Penelitian Kuantitatif, Kualitatif dan $R \& D$. Bandung: Alfabeta.

Suharman, S. (2012). Kaum samurai dan ajaran bushido dalam perspektif pendidikan karakter. Akademika: Jurnal Ilmiah Kependidikan, 12. Diakses dari https:// widyasari-press.com/kaum-samurai-dan-ajaranbushido-2/

Sulaeman, S. (2017). Isu integrasi dan disintegrasi: analisis terhadap buku teks sejarah Indonesia. Prosiding Seminar Nasional Berseri, 1(1), 145-152. Diakses dari https://proceedings.uhamka.ac.id/index.php/semnas /article/view/10

Tayama, K. (1908). Ippeisotsu. Diakses dari http://www.aozora.gr.jp

Wilson S. (1999) The Russo-Japanese War and Japan: Politics, Nationalism and Historical Memory. In: Wells D., Wilson S. (eds) The Russo-Japanese War in Cultural Perspective, 1904-05. London: Palgrave Macmillan https://doi.org/10.1057/9780230514584_8

Zafarayana, D. L. (2019). Militer dalam kejahatan perang Jepang terhadap Indonesia tahun 1942-1945 studi kasus: Perbudakan seksual wanita Indonesia. Journal of International Relations, 5(1), 235-243. Diakses dari https://ejournal3.undip.ac.id/index.php/jihi/article/ view/22766 